\title{
Intertextualidade na Fantasia "Wanderer" em Dó Maior Op.15 D.760 de Schubert
}

\author{
Intertextuality in Schubert's "Wanderer Phantasie" \\ in C Major Op.15 D. 760
}

\author{
Alexandre Fontainha Ficarelli \\ Universidade de São Paulo \\ ficarelli@usp.br
}

\section{Ciro Paulo Visconti Canellas}

Universidade de São Paulo

cirovisconti@usp.br

\author{
Amilcar Zani \\ Universidade de São Paulo \\ amilcarzani@gmail.com
}

Resumo: O artigo explora a significação musical na obra Fantasia em Do Maior, D.760 Op.15 (1822) para piano de Franz Schubert, que se baseia no Lied Der Wanderer, D.493, composto seis anos antes pelo compositor e que é citado no segundo movimento. A investigação parte primeiramente da fonte original e se expande por diversas vertentes procurando na forma, na harmonia, no ritmo, no contexto poético e na biografia do compositor, dar significado ao texto musical. O material composicional utilizado por Schubert revela uma relação com outras obras suas, tanto no aspecto estrutural/harmônico, quanto rítmico. Foram investigadas composições escritas anteriormente na tonalidade da obra, que trouxeram à luz dados relevantes. Um enfoque coeso sobre a integração temática da obra nos proporcionou a exploração tanto da intertextualidade quanto da narratividade.

Palavras-chave: análise musical; significação musical; intertextualidade; narratividade.

Abstract: This paper explores the musical meaning in the Fantasie in C major, D. 760 Op. 15 (1822), a piece for piano written by Franz Schubert based on one of his Lieds, Der Wanderer - D. 493, w ritten six years before. The Lied is quoted in the second movement. Our research begins looking into this primary source (Der Wanderer) and expands in several directions by seeking musical meaning in formal organization, harmonic connections, rhythmic approaches, poetic context and biography of the composer. Schubert's compositional material reveals a relation to other pieces

\section{MUSICA THEORICA}


written by himself or by others in both the structural/harmonic and the rhythmic aspect. Some previous works composed by Schubert in the same key as the one of the Fantasie were investigated, and shed light on relevant data. A cohesive approach to the thematic integration of the w ork enabled us to explore both intertextuality and narrativity.

Keywords: musical analysis; musical meaning; intertextuality; narrativity.

\section{1 - Introdução}

Schubert compôs a Fantasia em Dó Maior D.760 Op.15 no fim de 1822, depois de interromper os trabalhos em sua Sinfonia em Si menor (Inacabada). A Fantasia foi dedicada a Carl Emanuel Liebenberg von Zsittin, que estudara com Johann Nepomuk Hummel, segundo Alfred Einstein (1951, p.204), na esperança de alguma remuneração pela dedicatória.

É uma obra com quatro movimentos interligados, sem interrupção: Allegro con fuoco ma non tropo, Adagio, Presto, Allegro. Schubert baseou esta Fantasia num Lied que escrevera em 1816, chamado Der Wanderer Op. 4 nº 1, D. 489 (3 versão, antigamente com a atribuição D. 493), do qual ele empresta uma passagem citada no segundo movimento. A Fantasia apresenta uma estrutura rápido-lentoscherzo-rápido que é própria do gênero sonata. Entretanto o mesmo material temático, adaptado do Lied acima mencionado, é utilizado nos quatro movimentos, o que faz esta Fantasia se configurar com uma forma cíclica, uma solução sem precedentes nas sonatas para instrumento solo.

\section{2 - Sobre o Conceito de Wanderer}

Para começarmos a explorar o universo Schubertiano, necessitamos coletar todos os dados que possam estar relacionados com a expressão de algum significado na obra. Para tanto iniciamos explorando o significado do texto da canção. Começamos com o título da canção Der Wanderer.

O dicionário alemão-português Duden atribui à palavra Wanderer as seguintes acepções:

Wanderer - substantivo:

Alguém que (com prazer, disposição; frequentemente) caminha.

Wandern - verbo:

1. Caminhada, passeios a pé;

2. Caminhar sem um objetivo, caminhar (lazer);

3. Movimentar-se de lugar a lugar, a um destino remoto;

4. (Coloquialmente) Objetos que são trazidos (para uma finalidade específica) a um lugar delimitado. 
Psicologicamente podemos fazer alusão ao ato de caminhar na cultura europeia, da seguinte maneira:

1. A caminhada é um símbolo de uma árdua, mas significativa (idealisticamente motivada) aproximação de um destino.

2. O movimento da caminhada pela natureza tem um grande valor recreativo e de recuperação.

3. Caminhar sozinho resulta na libertação de todas as obrigações sociais e induz a meditação.

4. Qualquer um que contemple paisagens exuberantes, está num estado inconsciente do querer, passo a passo, progredir.

\section{3 - Contexto Poético}

Uma vez esclarecido o significado da palavra Wandern, podemos investigar significados do texto poético. Schubert utiliza um poema homônimo de Georg Phillip Schmidt 'von Lübeck' (1766-1849). A primeira versão da canção foi escrita em outubro de 1816. A data das outras versões é incerta, por isso se atribui o mesmo ano de composição da primeira versão para as demais.

As datas da publicação das diferentes versões são: 1821 ( $3^{\mathrm{a}}$ versão), 1895 ( $1^{\mathrm{a}}$ versão) e 1970 ( $2^{\mathrm{a}}$ versão). Por questões de clareza, a primeira versão leva o mesmo texto e outro título - Der Unglückliche (O Infeliz). Curiosamente o texto era atribuído anteriormente a outro poeta, a saber Zacharias Werner (1768-1823). O Lied foi dedicado a Johann Ladislaus Pyrker (von Felsö-Eör), um húngaro abade cisterciense, arcebispo e poeta.

O texto do Lied é o seguinte:

\section{Der Wanderer}

Ich komme vom Gebirge her,

Es dampft das Tal, es braust das Meer.

Ich wandle still, bin wenig froh,

Und immer fragt der Seufzer, wo?

Die Sonne dünkt mich hier so kalt,

Die Blüte welk, das Leben alt,

Und was sie reden, leerer Schall;

Ich bin ein Fremdling überall.

Wo bist du, mein geliebtes Land?

Gesucht, geahnt, und nie gekannt!

Das Land, das Land so hoffnungsgrün

Das Land, wo meine Rosen blühn.

\section{MUSICA THEORICA}


Wo meine Träume wandeln gehn,

Wo meine Toten auferstehn,

Das Land, das meine Sprache spricht,

O Land, wo bist du? ...

Ich wandle still, bin wenig froh,

Und immer fragt der Seufzer, wo?

Im Geisterhauch tönt's mir zurück:

"Dort, wo du nicht bist, dort ist das Glück".

A canção tem 72 compassos e é introduzida em Dó\# Maior. Depois de uma introdução de 6 compassos, o cantor começa um recitativo, descrevendo o cenário: montanhas, um vale envolto em neblina, o marulho. $\mathrm{O}$ andarilho a caminhar, infeliz, e suspirando, pergunta: "onde?"

A próxima seção, que consiste em 8 compassos de uma melodia lenta, é cantada em pianíssimo, em Dó\# menor. Descreve os sentimentos do andarilho: o sol parece frio, a flor murcha, a vida transcorre. O andarilho expressa a convicção de ser um estranho em qualquer lugar. Esta seção de 8 compassos corresponde à que foi usado por Schubert na Fantasia Wanderer.

Em seguida, há uma modulação para Mi maior, o andamento acelera e o compasso troca para 6/8. O andarilho pergunta: "Onde está você minha amada terra?" Este lugar é descrito pelo andarilho como verde como a esperança "a terra onde minhas rosas florescem, meus amigos passeiam, meus mortos ressuscitam" e finalmente, "a terra que fala a minha língua, Oh Terra, onde você está?"

Finalmente, a música retorna ao andamento lento original. Depois de citar a pergunta "Onde?" da abertura, a canção termina com uma "lufadafantasmagórica" finalmente respondendo a pergunta "Lá onde você não está, lá há felicidade" ao encerrar na tonalidade de Mi Maior.

O trecho usado na fantasia consiste na seção em Dó\# menor e corresponde à segunda estrofe que reproduzimos abaixo em tradução livre.

O sol friamente a me sombrear,

As flores murcham, a vida envelhece,

E o que eles falam, ruído permanece;

Sou um estranho em qualquer lugar.

No catálogo Otto Erich Deutsch ${ }^{1}$ aparecem apenas 12 obras nessa tonalidade, das quais somente 5 são instrumentais (Fantasia D.760, Sonata D.655, Momento Musical D. 780/4, Dança Alemã D. 643/1 e Minueto D.600). As outras 7 são canções.

\footnotetext{
1 Deutsch, Otto Erich. Schubert: A Thematic Catalogue of his Works. London, 1951; rev.1978. http://imslp.org/wiki/List_of_works_by_Franz_Schubert. Acesso em 08 de junho de 2017.
} 
Ao que pudemos observar, a angústia, a lamentação, o estado lúgubre atormentado, a inquietude, a escuridão, a morbidez, o macabro, a assombração, o desolamento, o soturno são algumas das características encontradas nas canções na tonalidade empregada por Schubert. As obras que se utilizam da tonalidade de Dó\# Menor com o mesmo espírito são: Der Unglückliche D.489 (1816) que é a $1^{\mathrm{a}}$ versão do Lied Der Wanderer (O Infeliz); Das Grab D.569 (1817) (O Túmulo); Der Jünglinge und der Tod D.545 (1817) (O Jovenzinho e a Morte); Thekla (Einer Geisterstimme) D. 595 (1817) (Thekla, Um Espírito); Mahommets Gesang D.549 (1817) (Fragmento - Canto de Maomé); e finalmente Nachtstücke D.672 (1825) (Peça Noturna).

A única exceção encontrada é o Lied Genügsamkeit D.143 Op. 109/2 (1815) (Modéstia) que não tem conexão com o espírito descrito das outras peças em Dó\# menor, contudo podemos notar que é a primeira obra nessa tonalidade escrita por Schubert. Segundo Elizabeth Mckay (1996), o estado de saúde de Schubert deteriorou-se a partir de 1816 quando teria tomado conhecimento da sua doença (sífilis), não curável à época.

É interessante observar como o poema é composto. Em grande parte ele se apresenta na primeira pessoa, contudo também existe o narrador em terceira pessoa, mas apenas em 3 frases: a que descreve o andarilho como o "suspirante" que pergunta "Onde?" duas vezes, e a frase que sela o final da canção, "Lá, onde você não está, lá está a felicidade".

A questão da narratividade de um poema remonta à antiguidade. Aristóteles estabelece a tricotomia da poesia, classificando-a como lírica, dramática e narrativa. No modo lírico, o poeta fala em sua própria voz; no drama, ele fala através das vozes de seus personagens; no modo narrativo, ele combina as duas técnicas. T. S. Eliot, em seu ensaio The Three Voices of Poetry (1954) demonstra sua visão sobre a essa divisão: o poeta falando para si mesmo (na letra em uma canção), endereçando ao público (recitando um épico) e assumindo o papel de um personagem (como no teatro).

Edward Cone (1974) menciona que alguns críticos não acreditam que o poeta fale em primeira pessoa. Eles creem que está sempre assumindo um papel, uma persona, mesmo quando essa persona é uma versão implícita do próprio poeta. A escolha do compositor provavelmente demonstra uma correlação intencional entre o texto de Der Wanderer e o sentimento da Fantasia Wanderer. Dentre muitas canções que Schubert escreveu, ele selecionou esta em particular, por algum motivo sobre o qual só nos restaria especular.

Hatten (1994), no capítulo Developing Gestural Variation in Beethoven Op. 90, oferece uma análise minuciosa do que ele chama de integração temática, que descreve como a mediação entre gestos musicais conflitantes. Embora preocupado principalmente com a evolução dramática desses gestos, Hatten apresenta em outro ensaio de 1993 (Schubert the Progressive: The Role of Resonance 
and Gesture in the Piano Sonata in A D.959) uma fórmula analítica útil, observando especificamente as características, semelhanças e diferenças de desenvolvimen to nas sonatas de Beethoven e Schubert. Nesse mesmo texto Hatten (1993) postula que qualquer expressão idiossincrática característica de um gênero envolve $o$ desenvolvimento de material germinal: "a realização única de um gênero expressivo convencional (como no caminho da luta trágica à vitória triunfante, aceitação transcendente ou devastação final) é muitas vezes dependente do curso afetivo mapeado pela variação em desenvolvimento de gestos temáticos". Hatten (2004) ressalta ainda: "para Beethoven e Schubert, o gestual da variação em desenvolvimento pode ajudar a gerar a estrutura e motivar o significado expressivo das principais obras em forma sonata". Note-se que traduzimos a expressão developing variations como "variação em desenvolvimento", conforme utilizado por Almada (2008).

\section{4 - Contexto Rítmico}

Analisando a citação do Lied na Fantasia, observamos que existe uma relação motívica entre os quatro movimentos da Fantasia que advém da célula encontrada na canção (Exemplo 1).

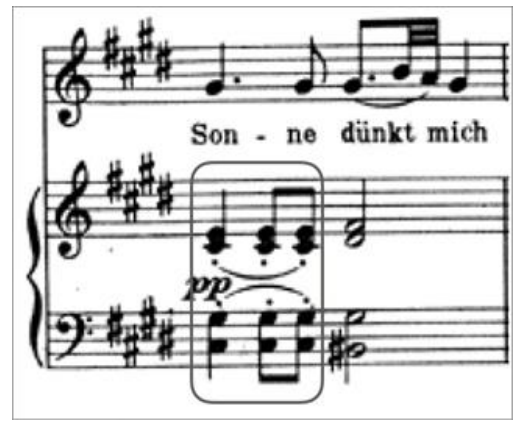

Exemplo 1: Motivo rítmico da canção Der Wanderer

Esse tipo de uso do ritmo nos remete ao verso épico. Para os gregos um poema era um arranjo de sílabas longas e breves que dava a estes, quando declamados, uma musicalidade característica. Foi usado extensivamente na epopeia, na lírica, na tragédia e na comédia.

A poesia grega usava vários metros, que eram combinações de sílabas longas (-) e breves ( - ), e essas formavam a estrutura básica dos versos, chamadas pés. A sucessão padronizada de pés emprestava ao verso um ritmo característico, lento e solene ou vivaz e agitado.

Os pés métricos mais importantes são: 


$\begin{array}{ll}\text { dáctilo: } & -\smile- \\ \text { anapesto: } & \sim- \\ \text { iambo: } & \sim- \\ \text { troqueu: } & -\smile \\ \text { espondeu: } & -- \\ \text { peon: } & -\smile-\end{array}$

Variações destes pés métricos eram também comumente utilizadas. A substituição de um pé dáctilo por um pé espondeu, por exemplo, era bastante frequente. Os dois tipos mais antigos de metro são o hexâmetro e o iambo.

Os poetas escolhiam os ritmos de seus versos segundo o efeito que desejavam produzir. Nas comédias, por exemplo, usava-se muito os versos iâmbicos, que se assemelhavam bastante à fala durante uma conversação comum. Na poesia épica, a mais antiga forma conservada de poesia grega, a preferência recaía sobre o hexâmetro dactílico, de efeito lento e solene. A poesia épica ou epopeia tem geralmente uma certa extensão e relata aventuras heroicas - míticas ou históricas - em estilo elevado.

O hexâmetro dactílico (ou "heroico"), constituía-se essencialmente de seis pés dactílicos ou seus equivalentes espondeus, cada um com um elemento bem marcado e outro mais fraco; o "tempo" bem marcado correspondia sempre a uma sílaba longa, e o "tempo" fraco a uma sílaba longa ou duas breves. Havia geralmente uma "pausa" ou cesura no meio do verso (terceiro pé), de modo a permitir a respiração do declamador. A Figura 1 ilustra a estrutura métrica do primeiro verso da Ilíada de Homero.

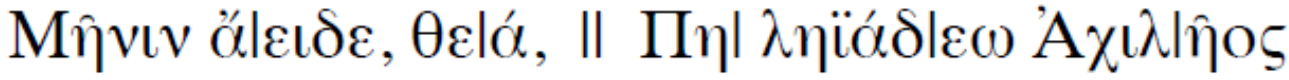

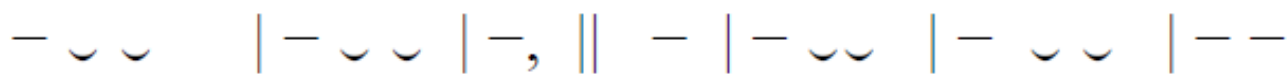

Figura 1: Estrutura métrica do primeiro verso da Ilíada de Homero.

Um dáctilo é uma sequência de três sílabas poéticas, a primeira longa e as duas seguintes breves. Portanto, o verso hexâmetro dactílico ideal consiste de seis (do grego hexa) pés, sendo cada um dáctilo. Tipicamente, porém, o último pé do verso não é um dáctilo, mas sim um espondeu ou um troqueu, ou seja, a penúltima sílaba é sempre longa e a última silaba pode ser breve ou longa (Ribeiro Jr, 2017).

A origem do nome dáctilo é a palavra dactilus, que significa "dedo" e faz alusão a extremidade do membro humano, com a primeira falange longa e duas seguintes breves, analogamente à sequência de sílabas longas e breves no verso. 


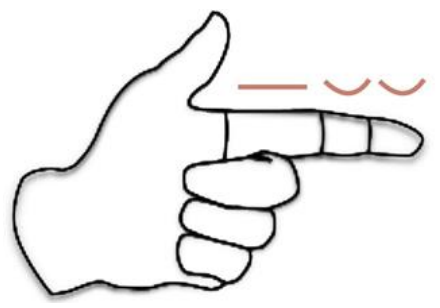

Figura 2: A sílaba longa e as duas breves dispostas nas falanges do dedo indicador

Podemos dar alguns exemplos de uso do ritmo dactílico. Do próprio Schubert temos as seguintes obras: Der Tod und das Mädchen D. 531, op. 7 n 3 (1817); Schwanengesang D. 744, op.23 no 3 (1822); Abendroth D. 799 (1824); além do próprio Lied Der Wanderer op. $4 \mathrm{n}^{\circ} 1$ (1816). Anterior a esses exemplos temos de Ludwig van Beethoven, a $7^{\text {a }}$ Sinfonia Op. 92 em Lá Maior, no 2o movimento Allegretto, de 1812, que utiliza os ritmos dáctilico e espondeu alternados. Observamos que em todas as obras o caráter solene e o andamento lento estão presentes. Esses exemplos podem ser verificados nas partituras em anexo.

\section{5 - Caminhos Harmônicos}

Dado o conceito do termo alemão Wanderer que elucidamos no item 2, consideramos necessário para a análise da Fantasia Wanderer determinar os caminhos harmônicos escolhidos por Schubert para a exposição do tema que é utilizado nos quatro movimentos. Este caminho levou a modulações entre tonalidades com poucas classes de altura em comum e por isso o compositor utilizou, como pivô das modulações, acordes simétricos que permitem possibilidades de reinterpretações enarmônicas.

Podemos ver um exemplo deste tipo de acorde no Lied Der Wanderer op.4 $\mathrm{n}^{\circ} 1$ D. 489 , de 1816, do qual o tema que aparece nos quatro movimentos da Fantasia foi tirado. O Lied alterna passagens em Dó\# Maior, Dó\# Menor e Mi Maior e no c. 54 o acorde de sexta italiana ${ }^{2}$ na função de dominante ganha um especial destaque com a fermata (Exemplo 2).

\footnotetext{
2 Utilizaremos os termos sexta italiana, sexta francesa e sexta germânica para designar os acordes de sexta aumentada mesmo quando eles não estiverem em sua função tradicional de dominante da dominante.
} 


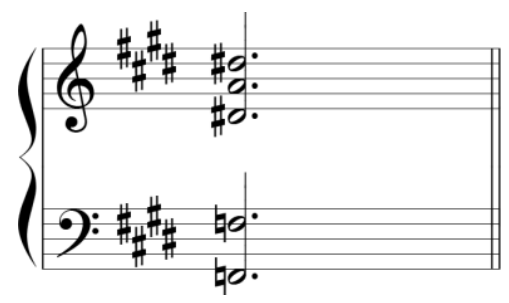

Exemplo 2: Acorde de sexta italiana no c. 54 de Der Wanderer

Certamente, o acorde de sexta italiana não é simétrico, mas se o consideramos como um acorde de sexta francesa incompleta (com a fundamental omitida), teremos um conjunto simétrico inversivo e transpositivo. Este mesmo acorde é utilizado no primeiro movimento da Fantasia Wanderer como pivô da passagem entre Dó Maior e Mi Maior como veremos adiante.

A utilização de acordes simétricos e de dupla interpretação enarmônica por Schubert já foi demonstrada por Richard Cohn (2012) em sua análise da abertura de Die Zauberharfe D. 644, de 1821 (portanto uma obra do ano anterior à Fantasia). Em sua análise, Cohn demonstra como Schubert caminhou entre as tonalidades de Mib Maior, Solb Maior, Lá Maior e Dó Maior utilizando as tríades aumentadas como pivô. Cohn, utiliza o grafo conhecido como Cube Dance para mostrar este caminho harmônico (Figura 3).

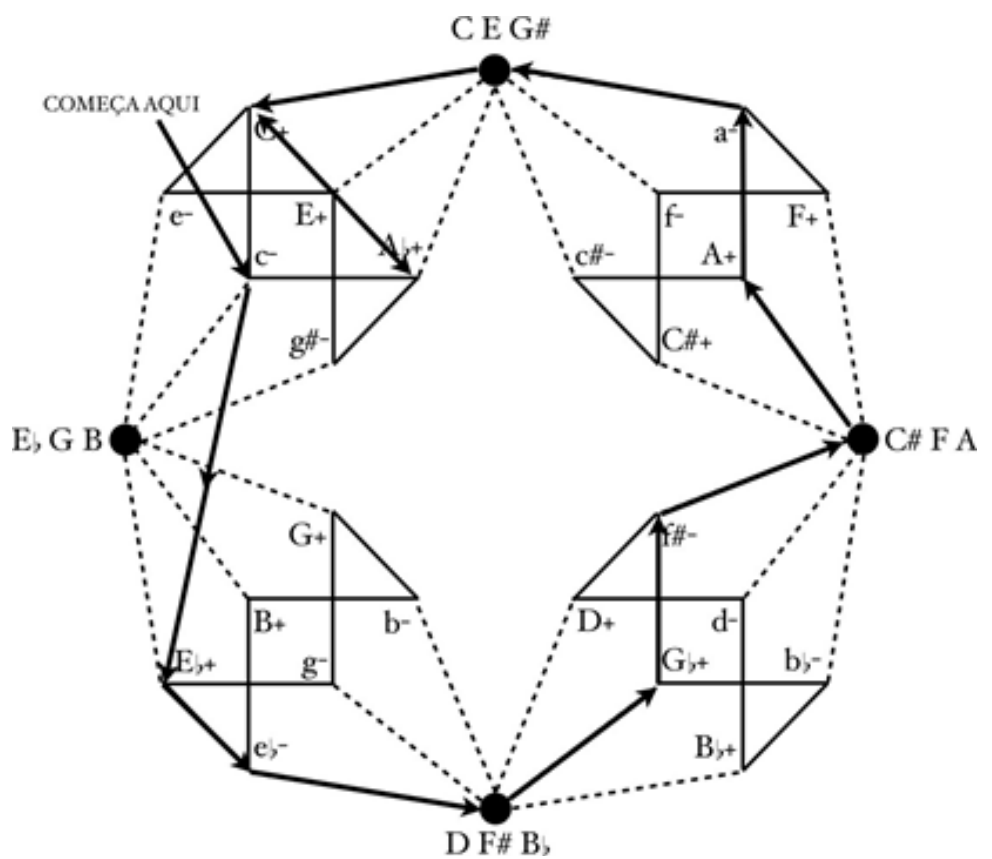

Figura 3: Caminho resultante da análise de Cohn da abertura de Die Zauberharfe traçado no Cube Dance (conforme Cohn 2012, p. 87, figura 5.4).

Na análise de Cohn, o caminho traçado pela harmonia mostra como os acordes maiores são tonicalizados (ou tonicizados, se preferirem) e as passagens entre eles são feitas com um acorde menor sempre seguido de uma tríade 
aumentada, como mostra o Exemplo 3.

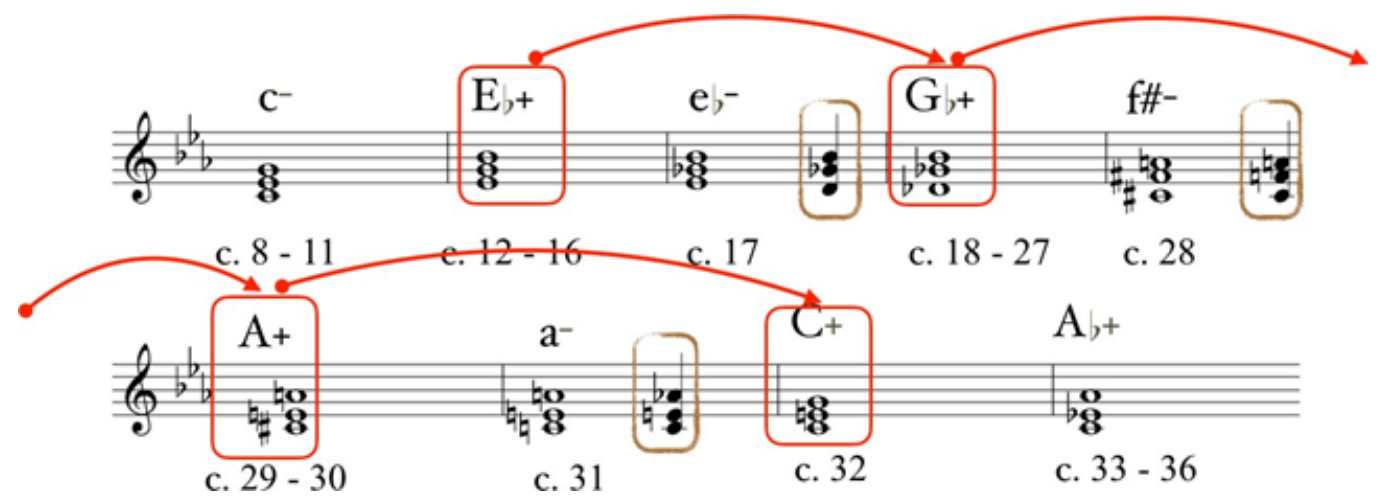

Exemplo 3: Caminho dos acordes da abertura de Die Zauberharfe

É notável como estas quatro tonalidades se dispõem em um círculo das quintas formando um quadrado que mostra que este é o caminho que as posiciona na maior distância possível entre si (Figura 4).

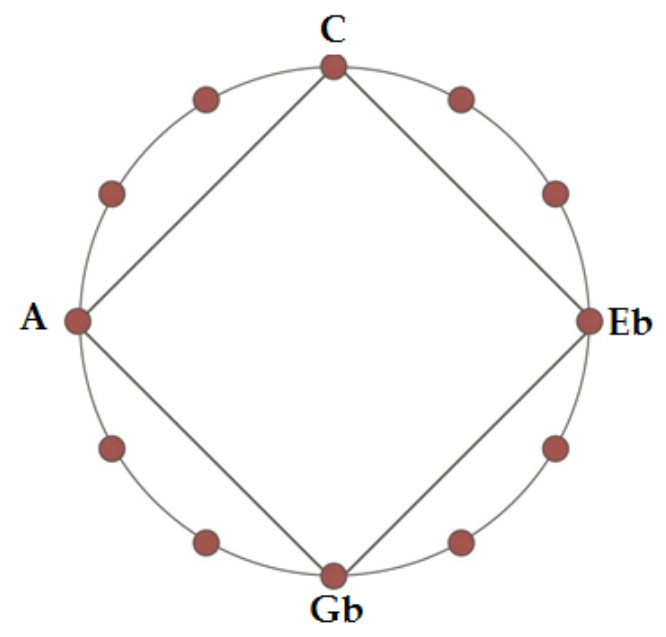

Figura 4: Disposição das quatro tonalidades maiores da abertura de Die Zauberharfe que formam um quadrado no círculo das quintas

Assim, esta que é a maior distância possível entre quatro tonalidades maiores é abreviada com a utilização da tríade aumentada - um acorde notadamente simétrico e de diversas significações enarmônicas - como pivô. Veremos como uma situação semelhante ocorre entre as tonalidades dos quatro movimentos da Fantasia Wanderer que se dispõem em um triângulo equilátero no círculo das quintas: primeiro movimento, Dó Maior; segundo movimento, Dó\# menor; terceiro movimento, Láb Maior; quarto movimento, Dó Maior. 


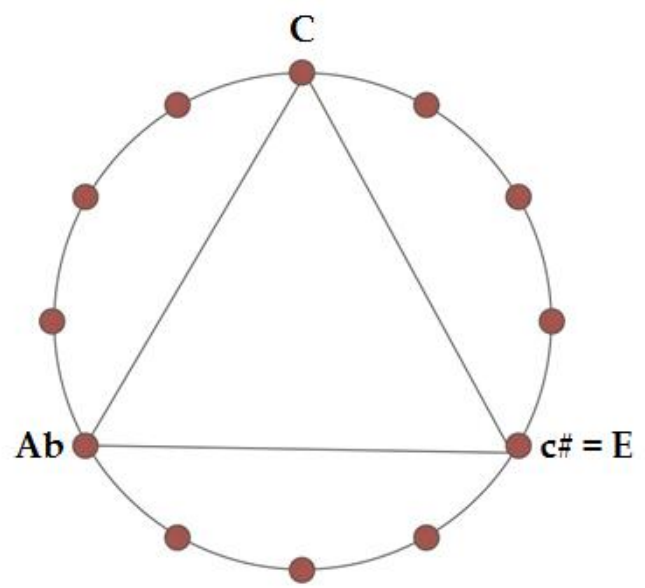

Figura 5: Disposição das tonalidades dos quatro movimentos da Fantasia Wanderer no círculo das quintas.

Assim como o quadrado é o caminho que posiciona quatro tonalidades na maior distância possível, o triângulo faz o mesmo com três tonalidades. De forma semelhante à abertura de Die Zauberharfe, Schubert irá conduzir a transição entre estas tonalidades com acordes simétricos que irão conectar os quatro movimentos. Desta maneira, o primeiro movimento, que está em Dó Maior, termina com um acorde com a função dominante para a tonalidade de Dó\# menor (tônica do segundo movimento) nos últimos 7 compassos (c. 181 a 188); este acorde dominante é introduzido através de um acorde de sexta francesa (c. 180), um acorde que, a exemplo da tríade aumentada, também é simétrico e tem possibilidades de reinterpretações enarmônicas (Exemplo 4).

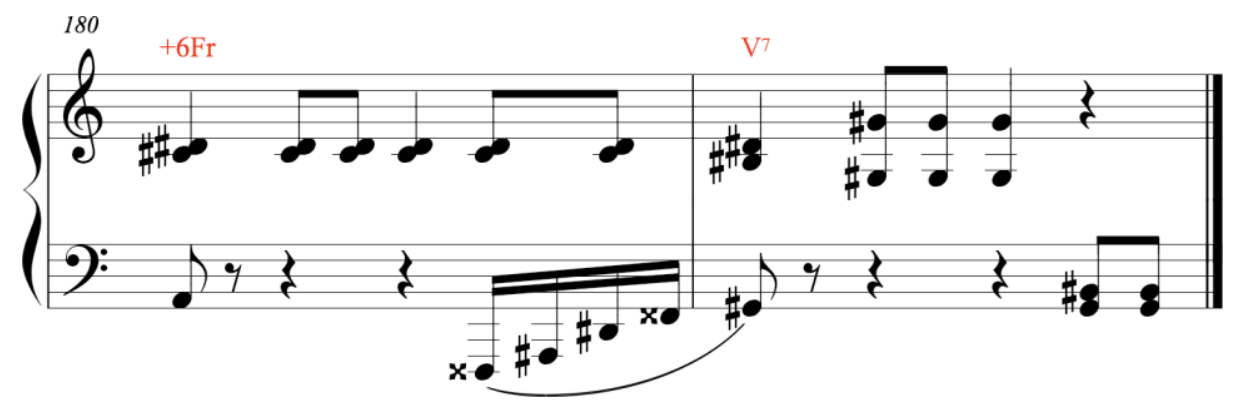

Exemplo 4: Introdução do V grau de Dó\# menor no final do primeiro movimento através de um acorde de sexta francesa.

A passagem entre o segundo e o terceiro movimento também é feita utilizando um acorde de sexta aumentada. Contudo, nesta transição Schubert se aproveitou da reinterpretação enarmônica do acorde de sétima de Mi Maior (Mi, Sol\#, Si e Ré natural) por um acorde de sexta germânica no c. 244 (Fáb, Láb, Dób e Ré, que não está escrito) que introduziria o V grau de Láb Maior no início do terceiro movimento. Este $\mathrm{V}$ grau, contudo, não se realiza e é apenas representa do 
pela nota Sol na primeira colcheia do compasso (Exemplo 5).
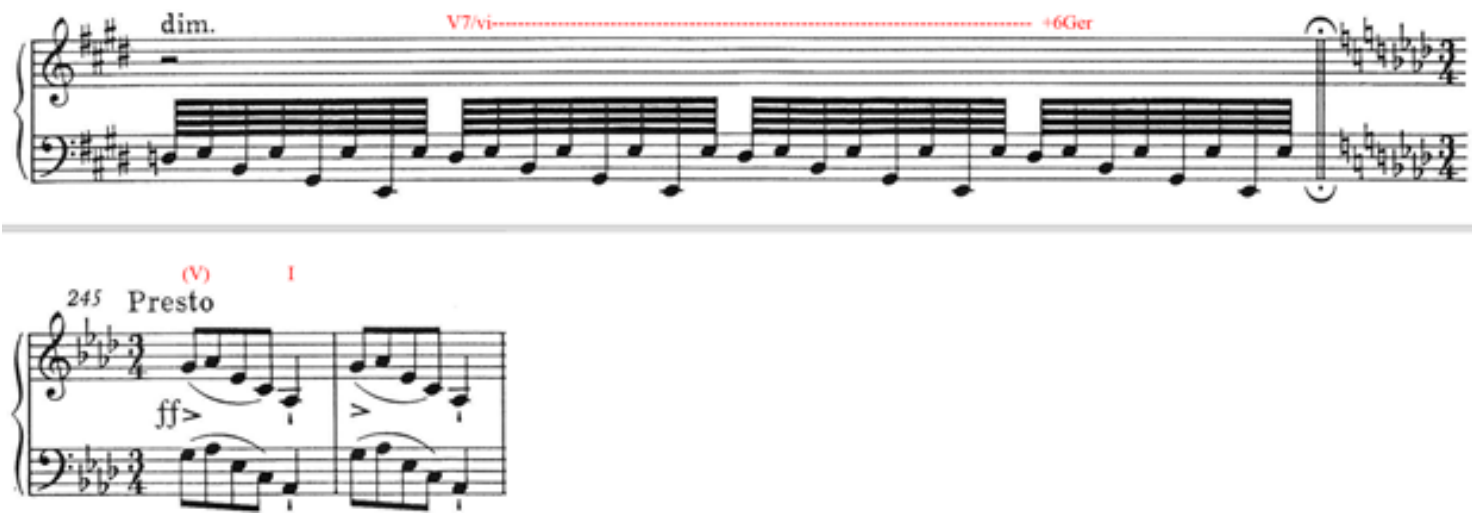

Exemplo 5: $\mathrm{O}$ acorde final do segundo movimento pode ser reinterpretado como um acorde de sexta germânica

Entre o terceiro e o quarto movimentos, a transição para Dó Maior também é feita através de um acorde de sexta germânica que soa por 8 compassos (c. 586593) e se encaminha para um acorde cadencial sobre o I grau (c. 594) antes de terminar na dominante da nova tonalidade (c. 596). (Ver Exemplo 6).
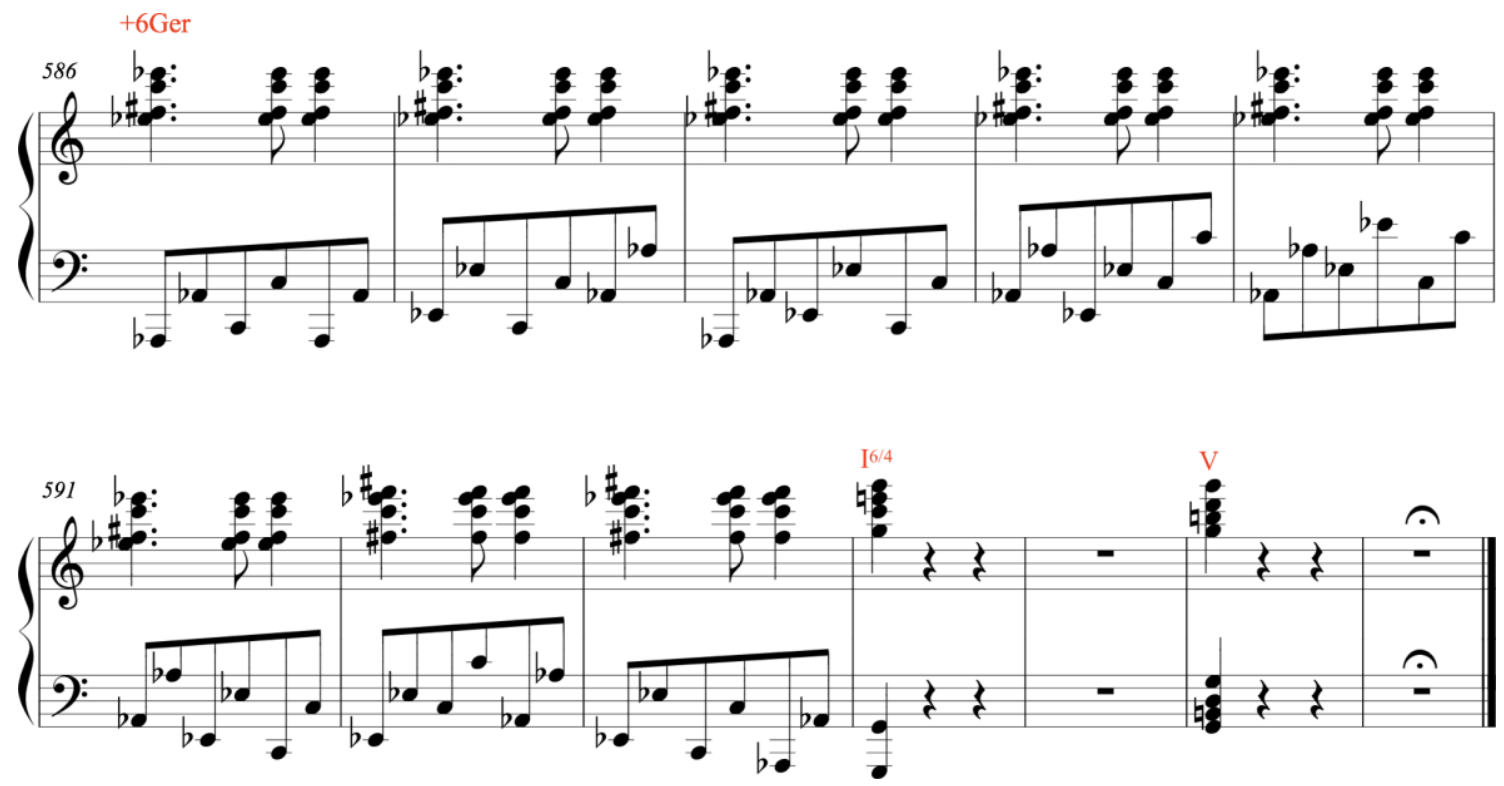

Exemplo 6: A introdução da Dominante de Dó Maior também é feita com o acorde de sexta germânica no final do terceiro movimento.

Assim, mesmo que os acordes da Fantasia misturem cardinalidades e desta maneira não seja possível mostrar seu caminho harmônico no Cube Dance ${ }^{3}$, é

\footnotetext{
${ }^{3}$ Ainda assim, seria possível descrever as transformações das tríades para as tétrades da Fantasia Wanderer com termos neoriemannianos se adaptássemos os conceitos de split e fuse de Callender (1998, p. 224).
} 
possível descrever um caminho geral de condução de vozes para as transições entre estas tonalidades (vide Exemplo 7), da mesma maneira que fizemos em relação à análise harmônica de Cohn para Die Zauberharfe no Exemplo 3.

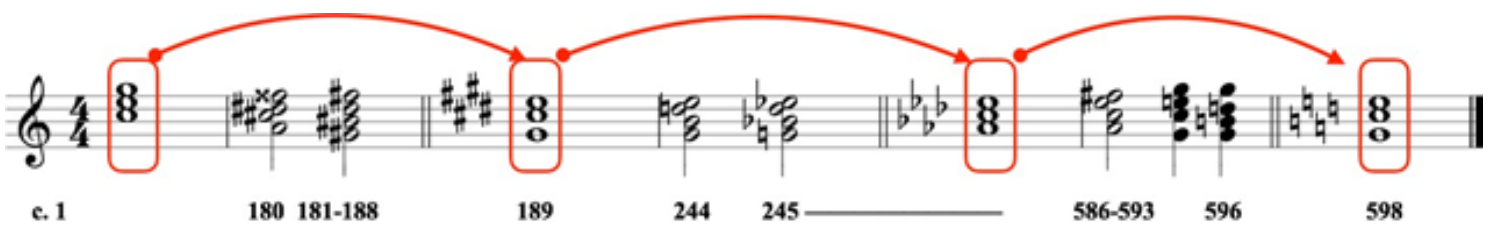

Exemplo 7: Caminho das tonalidades dos quatro movimentos da Fantasia Wanderer

Além disso, os acordes de sexta aumentada também aparecem na cadência dos temas principais do primeiro e do terceiro movimento. No primeiro movimento, o tema principal é uma sentença de 16 compassos que cadencia para a mediante de Dó Maior através do mesmo acorde de sexta italiana do Lied que destacamos no Exemplo 2. Ver Exemplo 8.
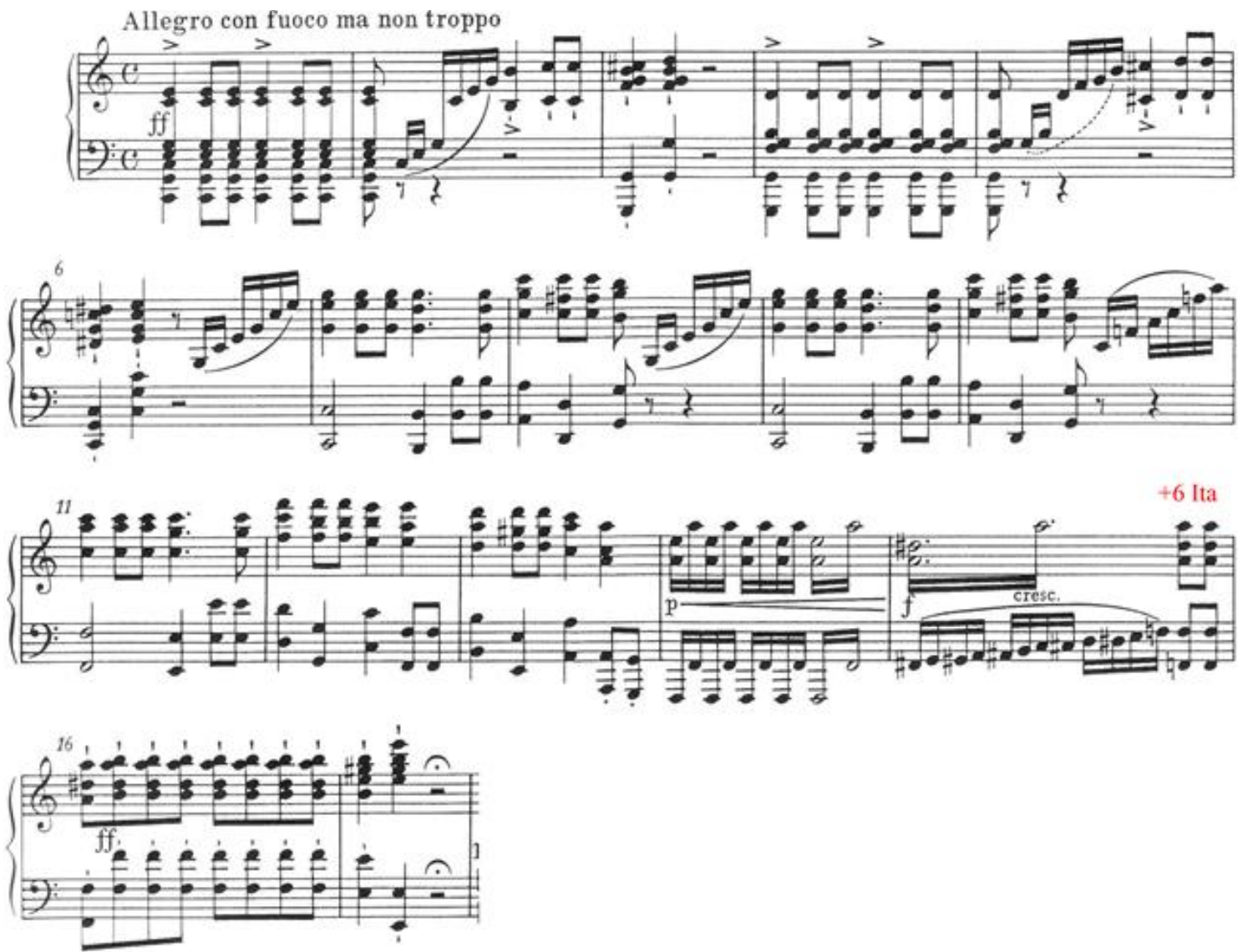

Exemplo 8: A cadência do tema principal do primeiro movimento é feita com o mesmo acorde de sexta italiana do Lied. 
No terceiro movimento, o tema principal termina com uma semicadência no acorde de Mib Maior no c. 273. Esta dominante é introduzida por um acorde de sexta francesa nos c. 271-272 (ver Exemplo 9).
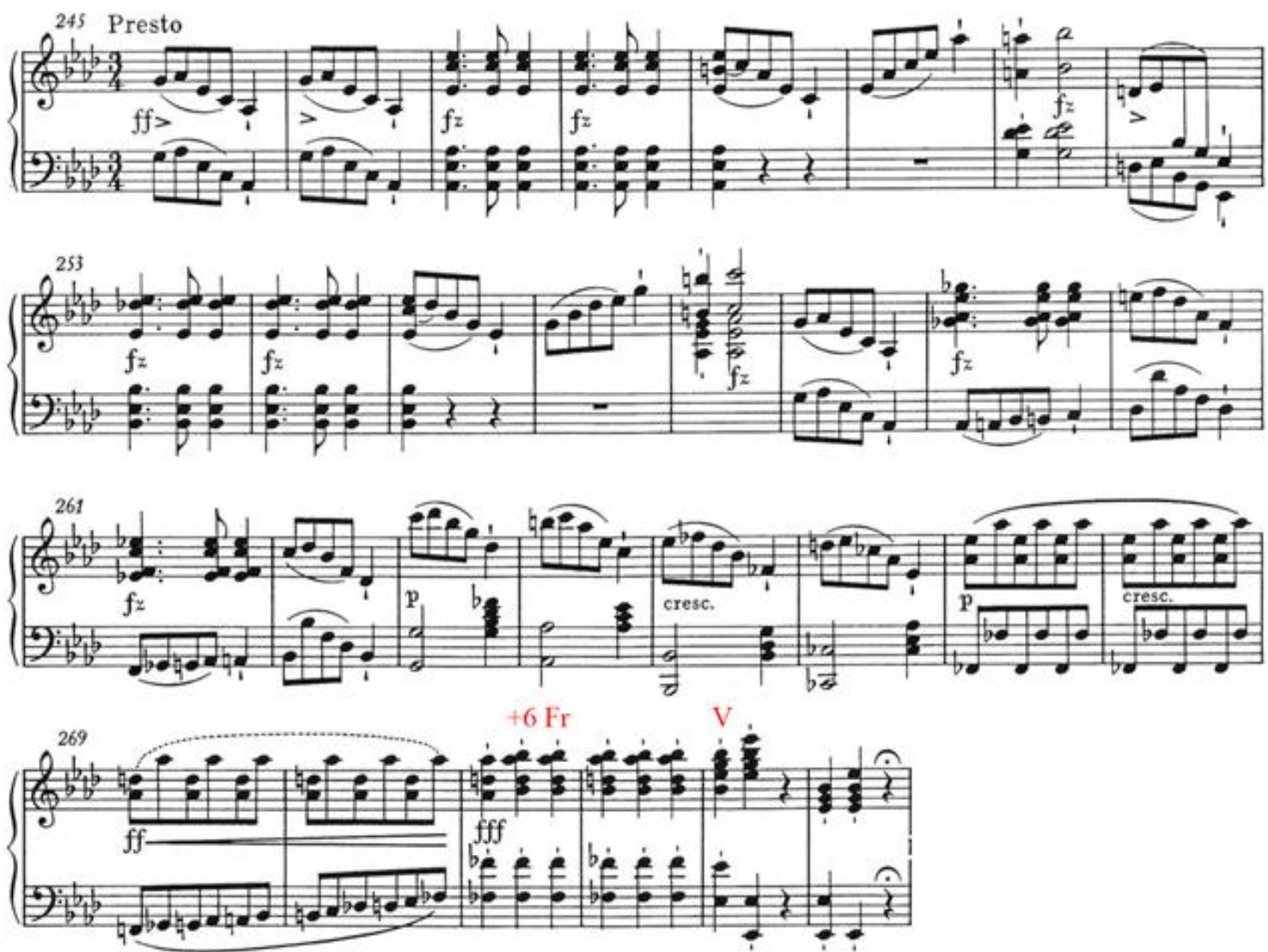

Exemplo 9: A semicadência do tema principal do terceiro movimento é feita com o acorde de sexta francesa sobre Fáb.

No segundo movimento, o tema aparece na mesma tonalidade e harmonia do Lied e, desta maneira, não há a introdução de acordes de sexta aumentada. Já no quarto movimento, o tema vira o sujeito de uma fuga a quatro vozes que tem muito mais um aspecto horizontal do que vertical. Consideramos que ela é uma fuga a quatro vozes, mesmo que ela não seja realizada à maneira tradicional como em Bach, por conta das vozes em oitavas e das entradas na mesma região. $\mathrm{O}$ Exemplo 10 mostra como dividimos a entrada de cada uma das quatro vozes dessa fuga. 

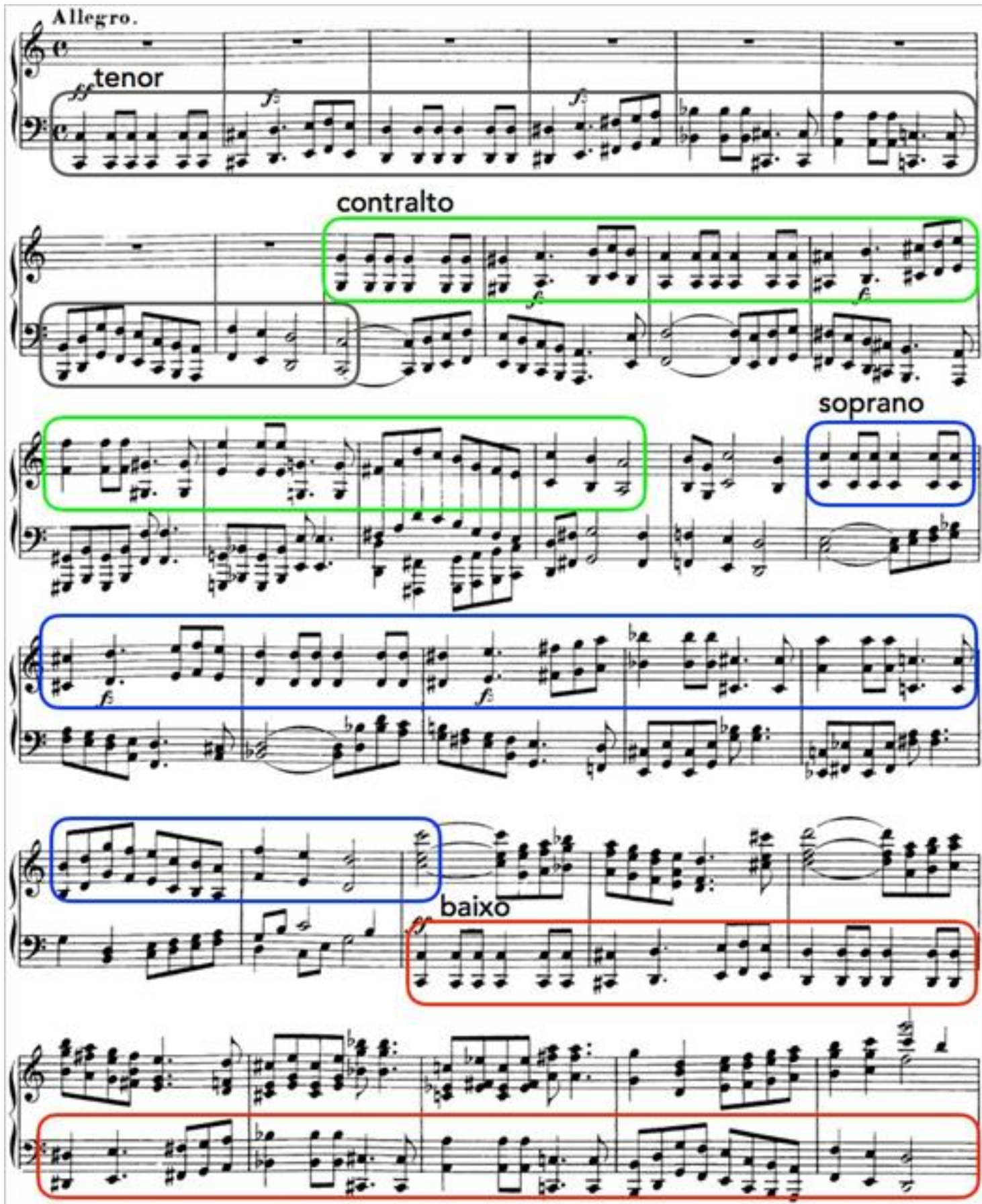

Exemplo 10: Entradas do sujeito da fuga do quarto movimento.

\section{6 - Considerações Finais}

Em nossa análise da Fantasia em Dó Maior D. 760, op.15 de Franz Schubert, nos deparamos com aspectos rítmicos, formais, melódicos e harmônicos que têm uma intertextualidade com obras de outros compositores (como Beethoven) e 
com outras obras do próprio Schubert (o Lied Der Wanderer Op. $4 \mathrm{n}^{\circ} 1$ e a abertura de Die Zauberharfe D. 644). Destacamos na análise cada um destes aspectos individualmente, com o objetivo de evidenciar estas inter-relações. Além disso, procuramos significá-las em relação ao título pelo qual a obra ficou conhecida, Wanderer Fantasie, buscando a conceituação do termo alemão além de sua utilização na poesia de Der Wanderer, Lied do qual o material temático da Fantasia foi baseado.

Quanto aos aspectos rítmicos, observamos pouca variação, dado o destaque ao ritmo dactílico, até mesmo porque quem caminha pode fazê-lo mais rapidamente ou mais lentamente. De certo que o ritmo apresentado no terceiro movimento - Presto - não é exatamente a definição de um ritmo dactílico, mas sim uma variação do mesmo. Observando a estrutura rítmica, ainda temos uma primeira nota mais longa e duas mais curtas. Poderíamos especular que o terceiro movimento em compasso ternário é um tropeço na caminhada, ou que aquele que caminha está mancando, sofrendo das injúrias, dos percalços da caminhada, do estado de saúde debilitado, fato esse que é citado por estudiosos da biografia de Schubert.

No aspecto harmônico, vimos como as três tonalidades dos quatro movimentos percorrem o caminho mais longo possível dentro de um círculo de quintas, descrevendo um triângulo equilátero (Figura 5). Vimos como Richard Cohn mostrou que Schubert já havia adotado um procedimento semelhante na abertura de Die Zauberharfe dispondo quatro tonalidades em um quadrado inscrito dentro do círculo das quintas (Figura 4). Na análise de Cohn, observamos que este caminho longo entre as tonalidades é percorrido através da utilização de um acorde simétrico e de múltiplas interpretações enarmônicas (a tríade aumentada) como pivô entre elas. Assim, pudemos mostrar que da mesma maneira as tonalidades distantes da Fantasia Wanderer se interligam por acordes de sexta aumentada (italiana, francesa e germânica) que desempenham o mesmo papel de pivô nas transições entre os movimentos. Observamos ainda que estes acordes de sexta aumentada também têm papel de destaque na cadência dos temas principais do primeiro e do terceiro movimento.

Quanto ao aspecto formal, Schubert desenvolve um material germinal inicial e consequentemente faz uso motívico dele para trazer unidade para a obra, fazendo desta um primeiro exemplo de sonata cíclica.

O primeiro movimento assemelha-se a uma forma sonata, mas é interrompido depois do desenvolvimento com a transição para o segundo movimento. Neste movimento o material temático é apresentado como uma sentença. O segundo movimento faz a citação quase literal da canção Der Wanderer em seus primeiros 8 compassos, seguida de uma série de variações sobre o tema. O terceiro movimento é um scherzo com trio e, a exemplo do movimento inicial, o material temático se apresenta como uma sentença, 
contudo, com uma organização mais frouxa em relação ao primeiro movimento. No quarto movimento, o material temático se transforma no sujeito de uma fuga a quatro vozes cujas entradas foram mostradas no Exemplo 10.

A significação se dá através dos múltiplos aspectos abordados e sua interrelação, nos remetendo a uma linha temporal. Charles Fisk (1989) examina as escolhas de Schubert sobre as principais seleções de tonalidade e sua interrelação. Ele sugere que a Fantasia Wanderer "dramatiza o surgimento da música em Dó\# Menor, mas também a integra no cenário de Dó Maior. Schubert também oferece, através da canção, uma chave para sua interpretação". Indubitavelm en te tanto o texto dramático como o uso da citação dentro da Fantasia são importantes e necessários para um exame minucioso da significação da obra. Fisk identifica um protagonista schubertiano nas suas composições para piano como "um caminhante em busca de si mesmo e de um refúgio tranquilo", como que "para aliviar sua aparente sensação de exílio e sua expectativa de morte prematura".

Os processos em que o material é transformado musical e expressivamente, contribuem para a construção de uma metáfora da experiência do protagonista. Comparado com o protagonista da canção, o personagem do Adagio da Fantasia Wanderer, emerge tonal e gestualmente como ainda mais estranho em relação ao seu entorno. Pode-se dizer que a fantasia incorpora a persona da canção e intensifica a sua Entfremdheit [estranheza] através do conflito dissonante entre Dó\# Menor e Dó Maior. Mas a persona da Fantasia como um todo confronta esse universo estranho.

Schubert criou uma forma de justapor estados de espírito, destacando a diferença entre regiões tonais remotas que podem sugerir a presença em sua música de conflitantes personae, isto é, de experiências incompatíveis dentro da mesma consciência. O desdobramento resulta em uma narrativa, eventualmente, de mundos díspares em um único, forjando continuidades musicais a partir de materiais que à primeira vista ocorrem desconexos. A música pode parecer vagar, mas vagueia dentro de cosmos tonais estruturados através da articulação sistemática das regiões tonais distantes. Dessa maneira temos a apresentação do personagem no primeiro movimento, a tragédia no segundo movimento, a superação no terceiro e a transcendência no quarto movimento.

Temos no primeiro movimento todo o material que será utilizado posteriormente na Fantasia Wanderer. Partindo desse ponto, enxergamos o primeiro movimento como a descrição/apresentação do personagem. No segundo movimento o conflito, a tragédia, possivelmente relacionada com a deterioração de sua saúde. O turning point, "a virada", se dá no terceiro movimento, na qual o compositor utiliza uma fórmula de compasso $3 / 4$ de caráter dançante, talvez dando as costas para a doença e prosseguindo em sua vida. No quarto movimento, um gran finale em estilo elevado, com uma fuga representando a transcendência a outro plano. 
Segundo Albert Lavignac (1933), “uma fuga é uma peça de música inteiramente concebida em contraponto, onde tudo se interliga, direta ou indiretamente, a um motivo inicial denominado sujeito". Em análise sintática, o sujeito é um dos termos essências da oração, geralmente responsável por realizar ou sofrer uma ação ou estado. Nesse sentido, o compositor faz uso do material temático do primeiro movimento como sujeito central de toda a obra que culmina no sujeito da fuga, mostrando a conexão e a inter-relação do personagem ao longo de toda a obra. Por outro lado, o elo com a realidade é que Schubert veio a falecer apenas 6 anos após a composição da Fantasia Wanderer, não obstante compondo ainda cerca de 250 obras.

\section{Referências}

1. Almada, Carlos. 2008. O conceito de variação em desenvolvimento no primeiro movimento da Sonata para Piano op. 2 nº 1, de Beethoven. Música Hodie, v. 8.

2. Callender, Clifton. 1998. Voice-Leading Parsimony in the Music of Alexander Scriabin. Journal of Music Theory, Vol.42, No. 2, Neo-Riemannian Theory, p. 219-233.

3. Cone, Edward T. 1974. The Composer's voice. Berkeley: University of California.

4. Cohn, Richard. 2012. Audacious Euphony. Oxford: Oxford University Press.

5. Eliot, Thomas Stearns. 1954. The Three Voices of Poetry. Cambridge: Cambridge University Press.

6. Fisk, Charles B. 1989. Edward T. Cone's The Composer's Voice: Questions about the Persona of Schubert's "Wanderer" Fantasy. College Music Symposium.

7. Hatten, Robert S. 2004. Musical Meaning in Beethoven. Bloomington: University of Indiana Press.

8. 1993. Schubert the Progressive: The Role of Resonance and Gesture in the Piano Sonata in A, D.959. Integrál 7.

9. Lavinac, Albert. 1933. La musique et les Musiciens. Paris: Librairie Delagrave.

10. McKay, Elizabeth N. 1996. Franz Schubert: A Biography. Oxforf: Clarendon.

11. Ribeiro Jr., W.A. O verso Épico. São Carlos: Portal Graecia Antiqua.

URL: greciantiga.org/ arquivo.asp?num=0161. Acesso em 08 de junho de 2017. 


\title{
ANEXOS
}

\author{
Der Tod und das Mädchen.

Sckabert's Werke Fur eine Singstimme mit Begleitung des Pianoforte

\section{FRANZ SCHUBERT.

Mässig. d.u.

Etwas geschwinder.

Singstimme.

Pianoforte.
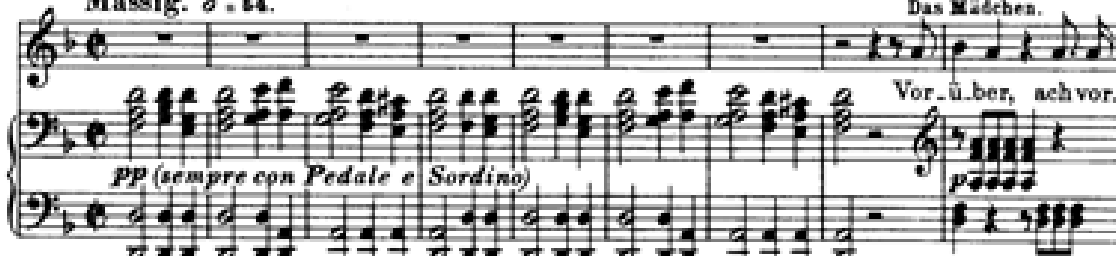

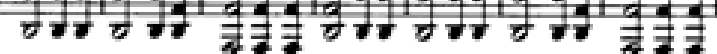

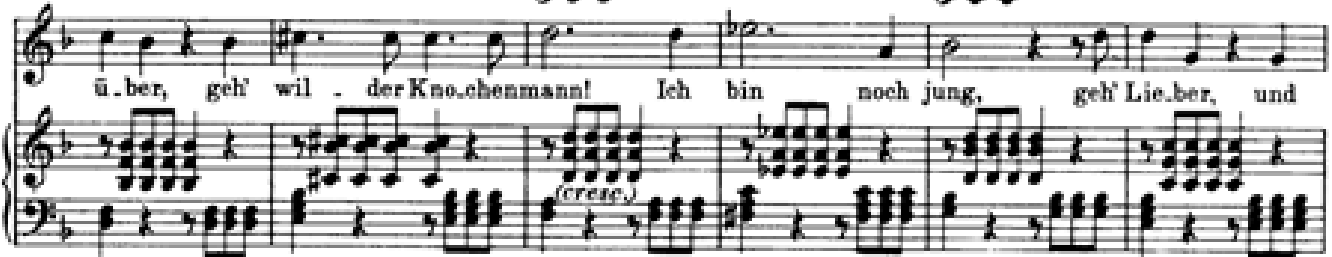

Wie oben.
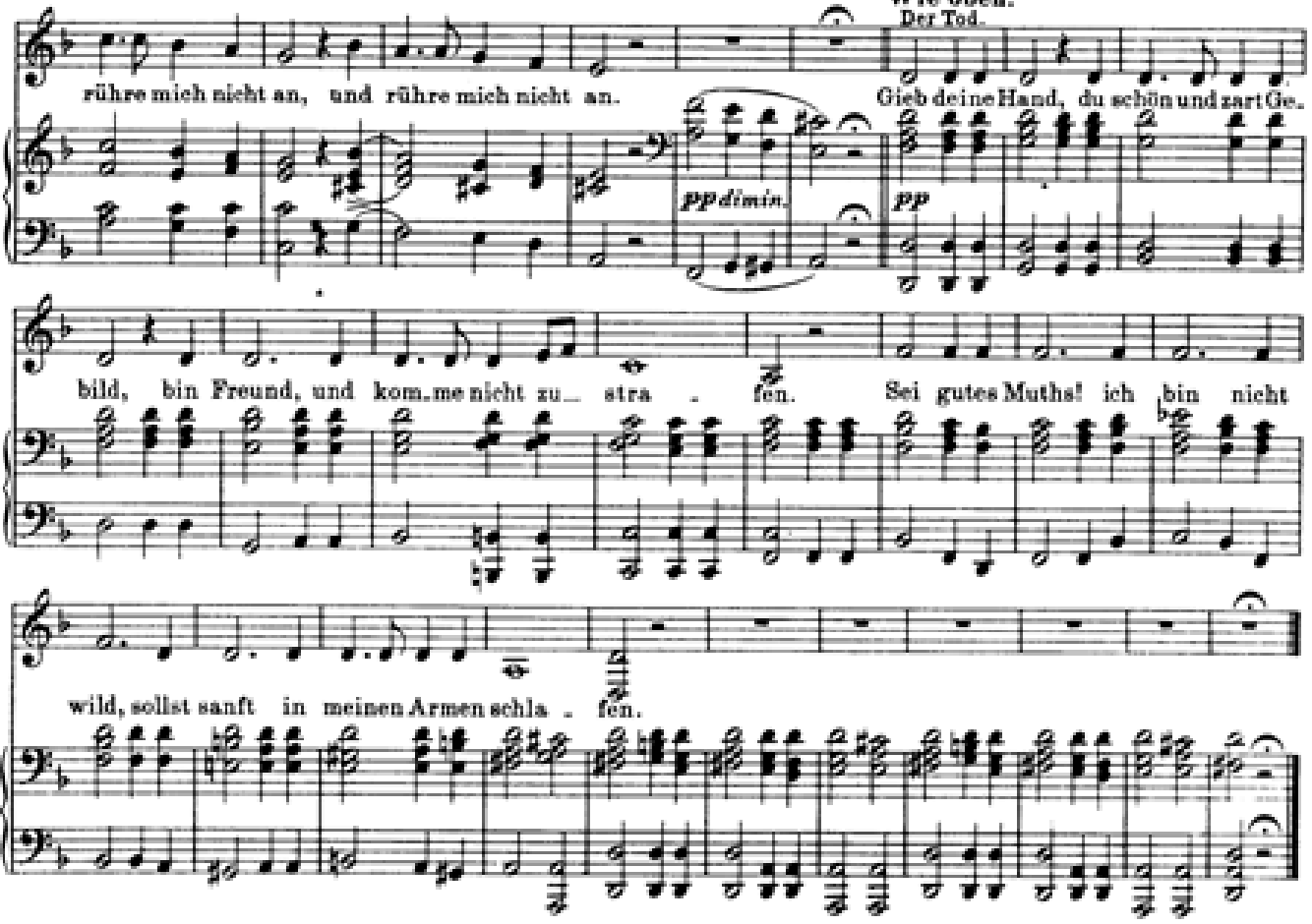

Schubert - Der Tod und das Mädchen D.531 op. 7 n 3 (1817) 
2 (16)

\section{Schwanengesang.}

Gedicht von Joh. Senn.

Für eine Singstimme mit Begleitung des Pianoforte

componirt von

No 407.

\section{FRANZ SCHUBERT.}

Op. 23. No 3.

Sehr langsam.
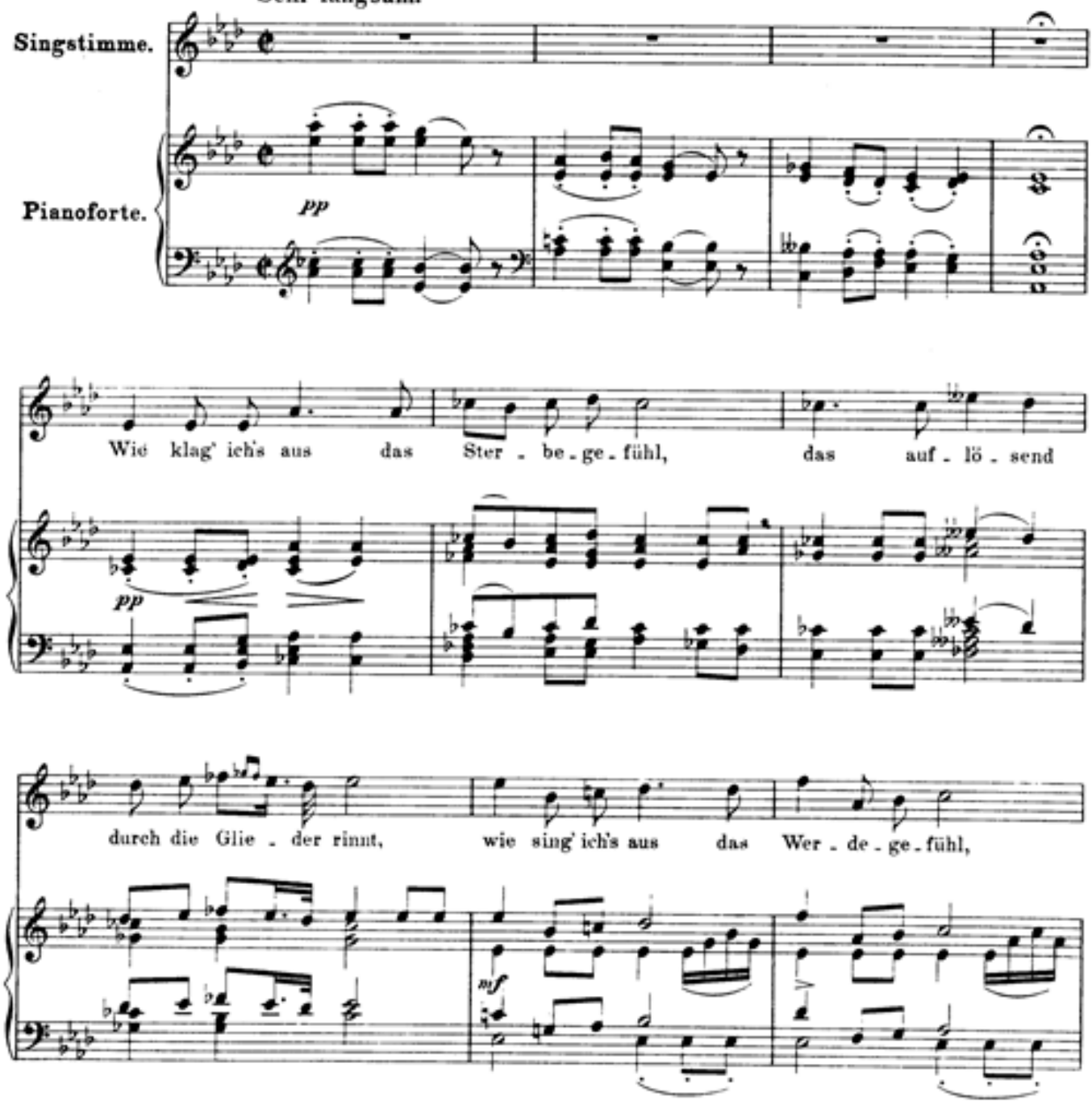

Schubert - Schwanengesang D. 744 op. $23 \mathrm{n}^{\circ} 3$ (1822) 
? (30)

Schubert's Werke,
Im Abendroth.

Gedicht von Carl Lappe.

Für eine Singstimme mit Begleitung des Pianoforte

componirt von
Serie 20. NP 463.

\section{FRANZ SCHUBERT.}
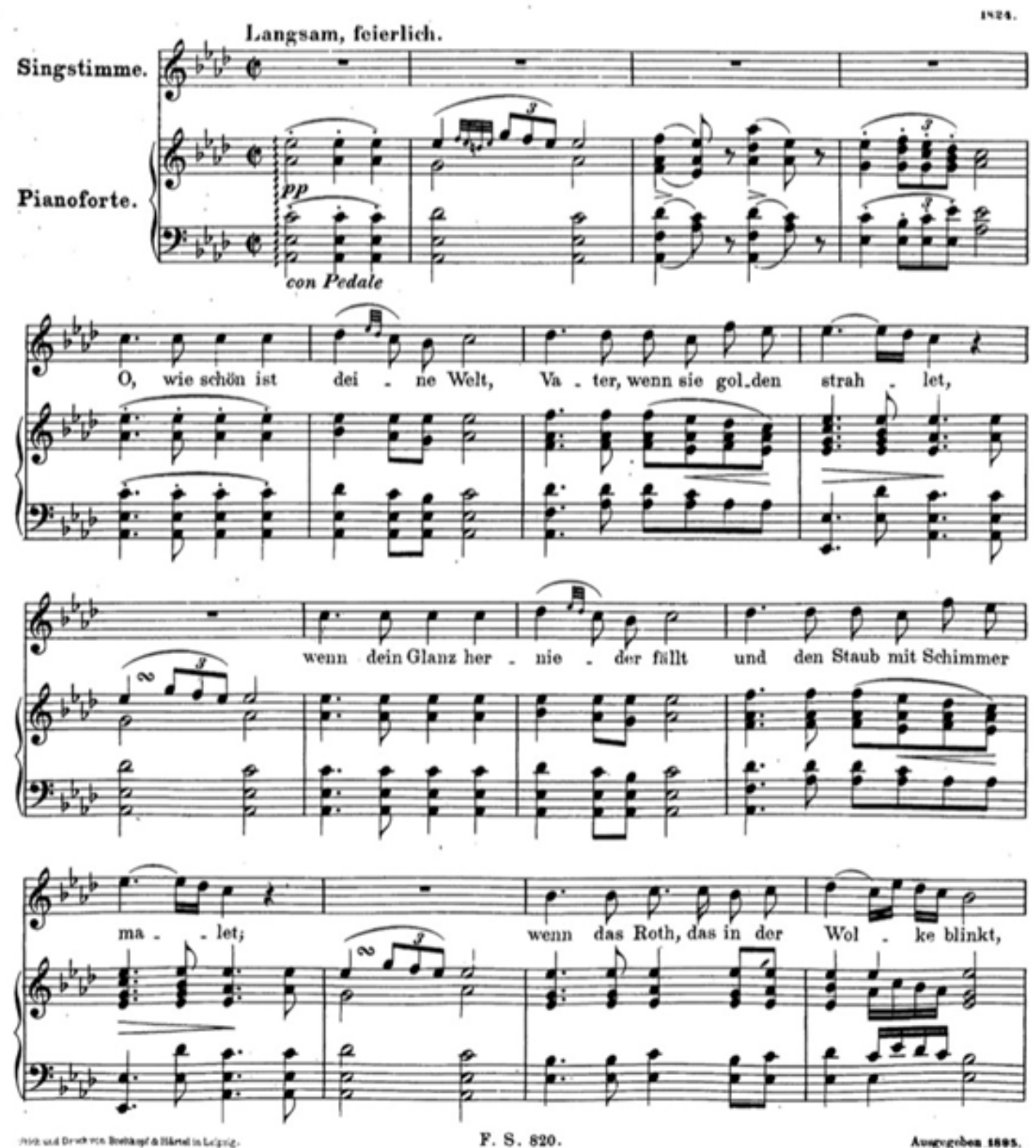

Schubert - Im Abendroth D.799 (1824) 
184

4.

Der Wanderer.

Setmiat ron Ltbeck.

62.
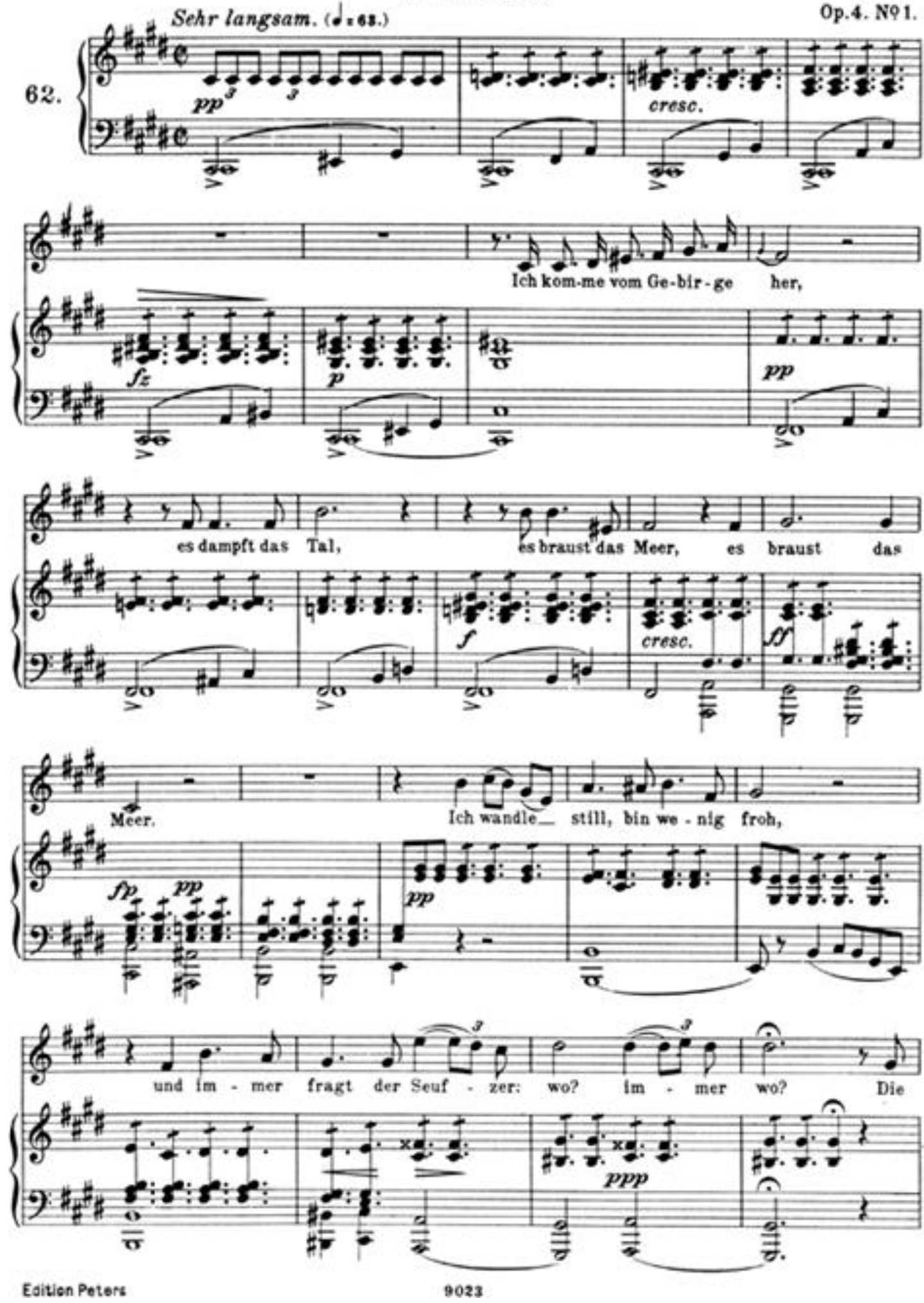

Schubert - Der Wanderer op. $4 \mathrm{n}^{\circ} 1$ (1816) - p.1

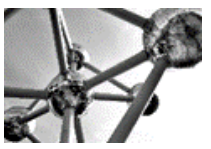



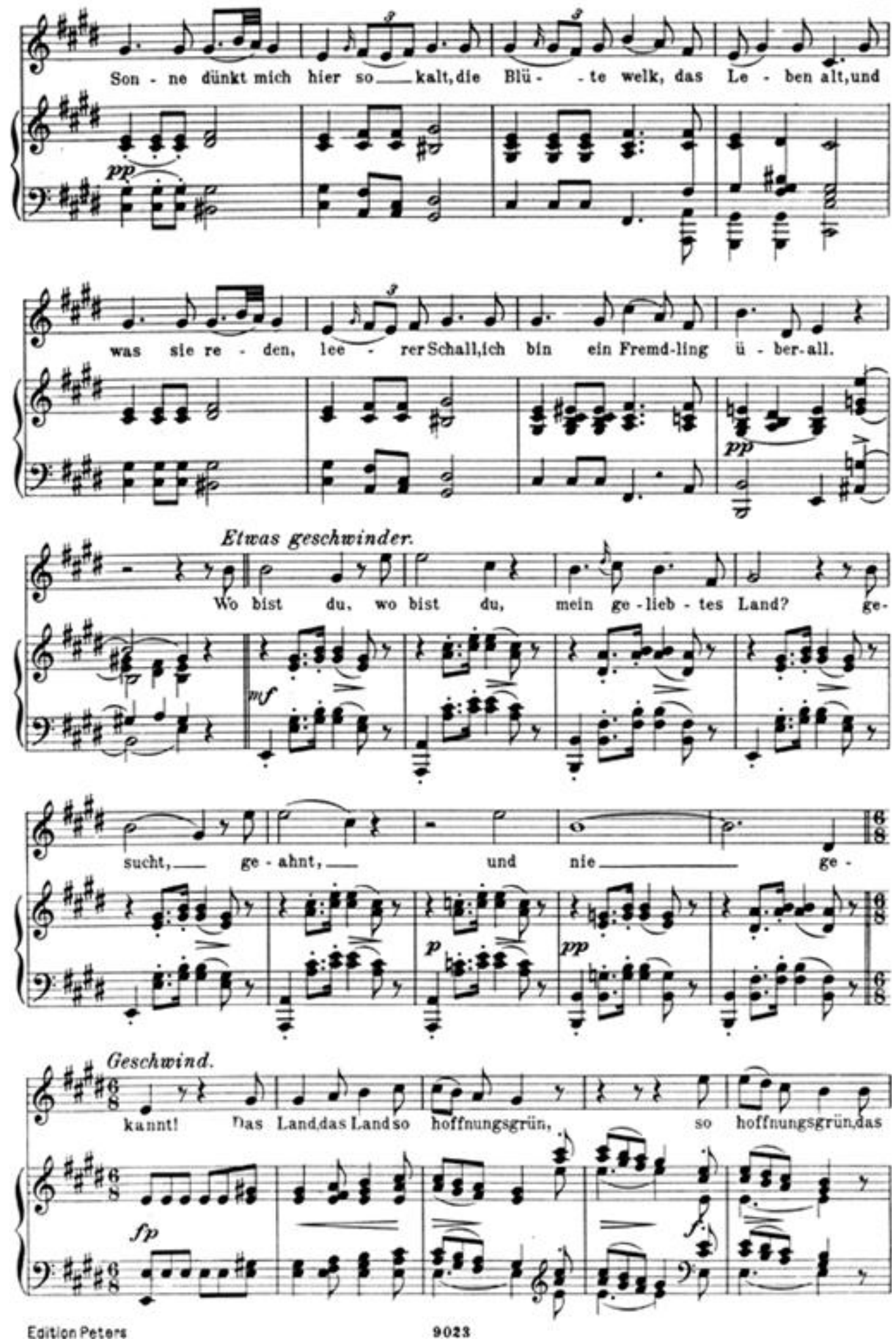

Schubert - Der Wanderer op. $4 \mathrm{n}^{0} 1$ (1816) - p.2

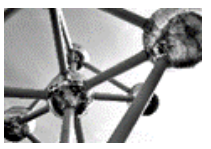


186
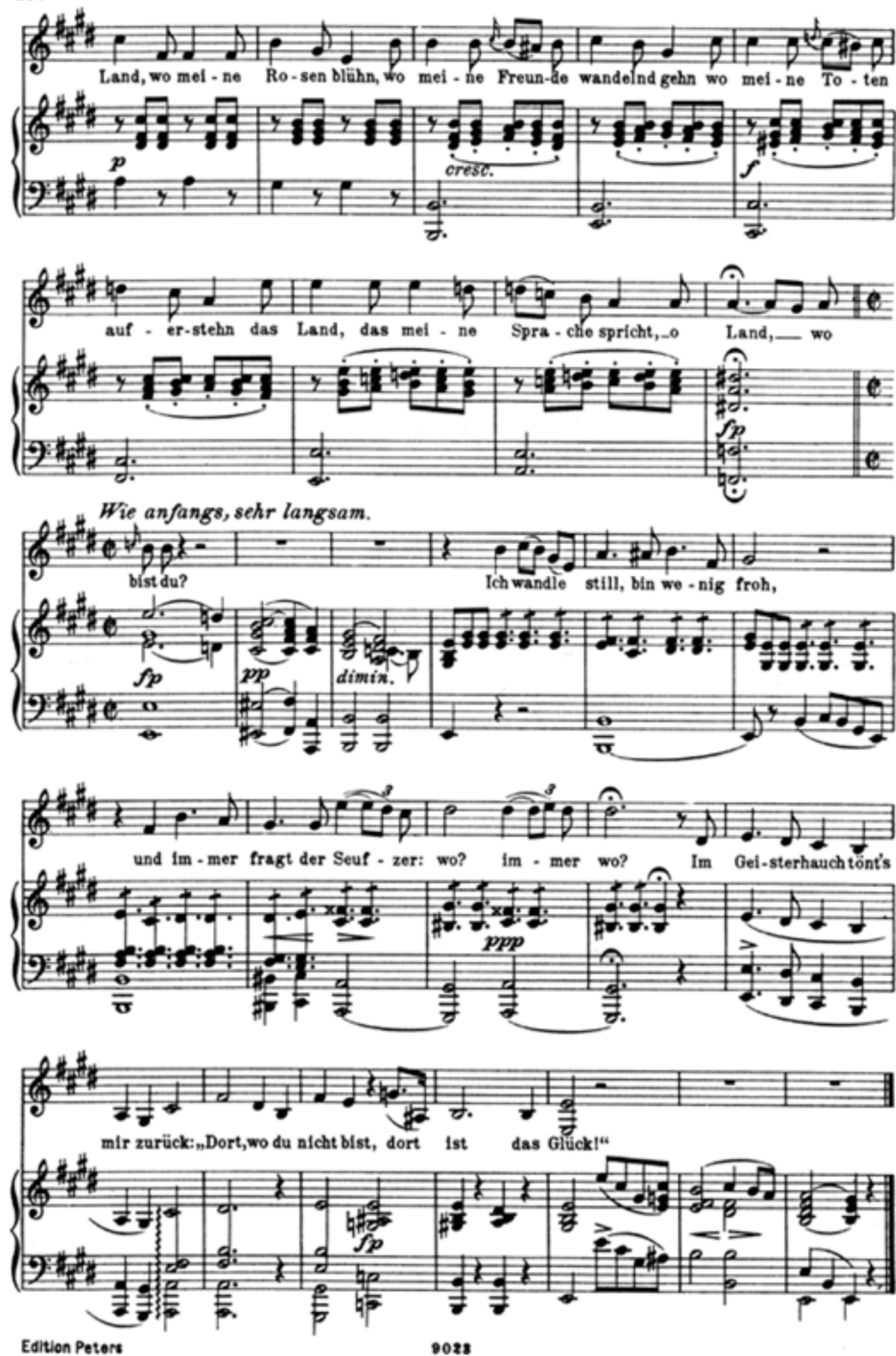

Schubert - Der Wanderer op. 4 no 1 (1816) - p.3 

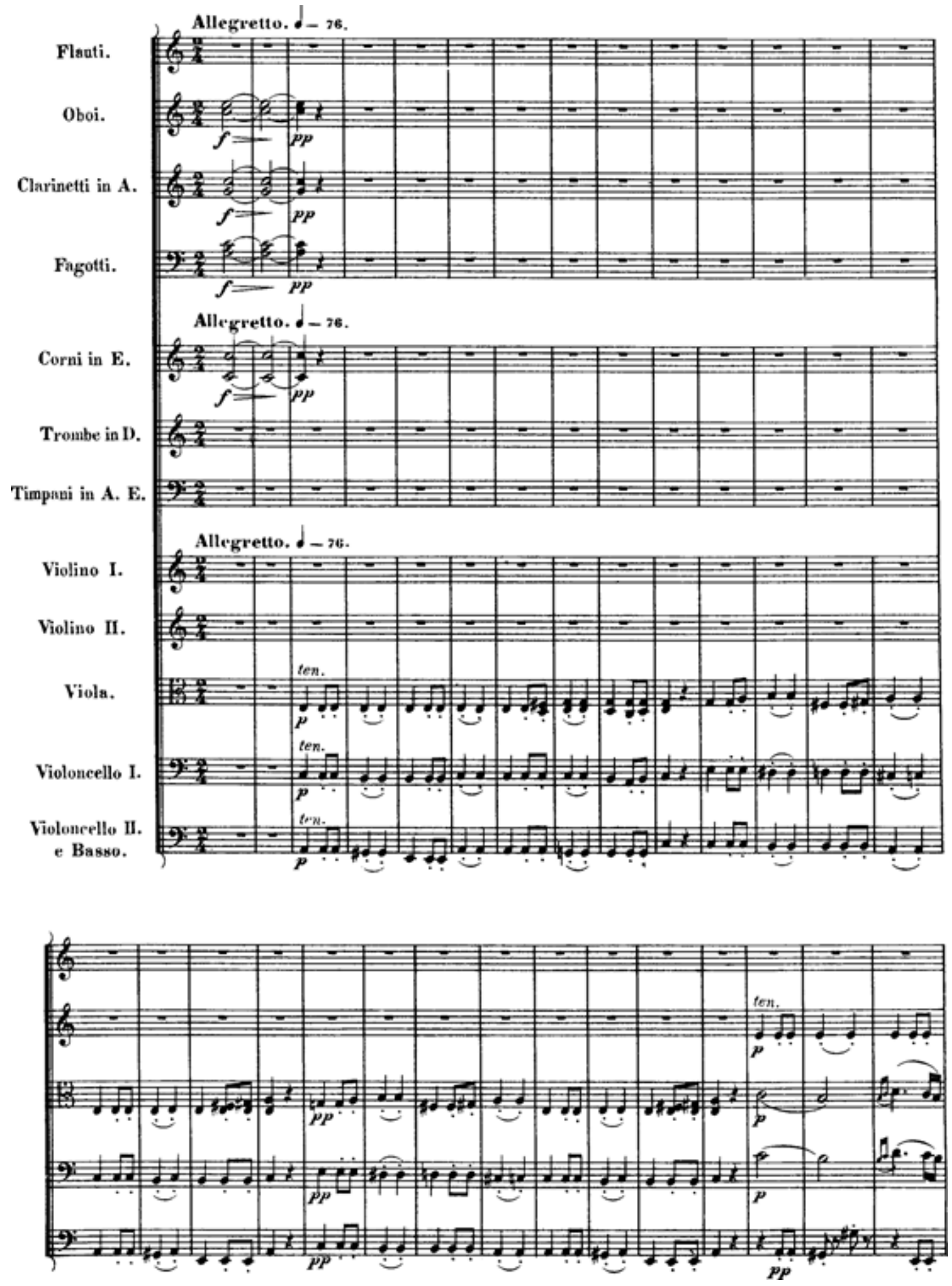

Beethoven, 7a. Sinfonia op.92, Segundo Movimento: Allegretto 